\title{
"Middle Income Trap"; The Position of Algerian Economy: A Comparative Analysis Overview
}

\author{
Allaoui elhassen ${ }^{1}$, Tidjani chems eddine ${ }^{1}$, Lacheheb miloud ${ }^{2}$ \\ ${ }^{1}$ Department of Economic Sciences, Faculty of Economic Sciences, Commercial, and Business Sciences, University of Kasdi Merbah, Ouargla, \\ Algeria \\ ${ }^{2}$ Department of Economic, Faculty of Economics and Management, University of Putra, Selangor, Malaysia
}

Email address:

elhassen.allaoui@gmail.com (A. elhassen), tidjani.chemseddine@univ-ouargla.dz (T. c. eddine), miloulach@yahoo.fr (L. miloud)

\section{To cite this article:}

Allaoui elhassen, Tidjani chems eddine, Lacheheb miloud. "Middle Income Trap"; The Position of Algerian Economy: A Comparative Analysis Overview. International Journal of Economics, Finance and Management Sciences. Vol. 3, No. 4, 2015, pp. 337-346. doi: 10.11648/j.ijefm.20150304.12

\begin{abstract}
Economic history has shown that few middle-income countries have successfully attained high-income level. Effective transition from middle to high-income level requires an efficient resource use, private sector improvement, productivity enhancement, and technology based rather than labor based production. Failure of doing so, undoubtedly, leads to income trap, whereas a country caught in middle-income level for a long period. Therefore, this paper attempts to highlight the Algerian economy patterns since its independence to current position with regard to middle-income trap criteria, likewise, reasoning the causes that headed Algeria to middle income trap for over 30 years. Moreover, this paper goes further ahead in cross-country evidence of how Algeria compares with peer countries from MENA region. Likewise our results shows that the Algerian economy has better position than Egypt and Yemen. However, Algeria is still behind UAE that classified in high-income level, where Algeria has known a slow growth rate during the last 50 years. Finally, remedies are suggested as a way out from middle-income trap, and to promote high growth rate in order to achieve high-income level in the future.
\end{abstract}

Keywords: Algerian Economy, Comparative Analysis, Economic Position, Middle-Income Trap, MENA Countries

\section{Introduction}

Most of the economies across the globe tend to attain sustained growth rate and eventually catch up with high developed countries, yet many of them fail to do so. For many different factors, it can oblige these countries to seek decades in "low economic" situation, or it has "low income" level, from the point view of income (GDP) as a principal measuring indicator.

Most of under developing nations in most case suffering from low income level, which has gone through a war, political turmoil, socialist planning, and severe economic mismanagement is usually characterized by a fragile economic structure (i.e.: Vietnam, Philippines,... etc.) Kenichi Ohno (2009). But some of them have found or tried to find a successful way out to their situation like the Asian and Latin Americas countries experiences (i.e.: Malaysia, Thailand, China, and Brazil, Argentina, Chile, ...etc) (Tran. V. T, 2013, Yanrui. W, 2013, Kanapathy. V, Herizal.h, Pasuk. P, and Pornthep. B, 2013, Aaron. F, Ejaz. G, Saurabh. M, 2013,
Anna.J, Arne. N, and José. R. P, 2012). While some others have not taken a serious step and decision to overcome their weakness. Consequently, they fall into what is known as an "income trap" (Gill and Kharas, 2007, Felipe, 2012, Eva paus 2012, Gianluca. G, Marco Vivarelli, 2010).

Therefore, from a point of comparison between MENA countries economic situation. So what is the position of the Algerian economy among MENA countries?

Our paper aims to give an overview about the concept of "low, middle, \& upper income trap", and specifically we will take the case of Algerian economy with a comparative analysis against selected countries from MENA region. Moreover, the study analysis based on World Bank Database, that represents the GDP/capita of Algerian economy and other countries, for fifteen last years (1963-2013).

This paper is organized in three main sections; the first section contains a theoretical criteria \& concepts that are related to the "Middle income trap", along with literature review based on this study. In the second section, we will give an analysis about the position of the Algerian economy in comparison with other MENA countries. The last section 
shows the different aspects, reasons, and effects of "Middle-income trap" in the Algerian case. Finally, recommended policies and appropriate remedies will be suggested as a way out from this trap.

\section{Literature and Concept Background of the Middle Income Trap}

\subsection{Literature and Contribution}

\subsubsection{Literature Review}

Return to the recent history reviews, this concept has received an interest by researchers and policy makers, since many countries have a rapid growth rates that allowed them to reach middle-income trap status. Thus, different studies and working papers focused on this phenomenon, while the term "middle-income trap" was apparently first used by Garret (2004) in his analysis on the effects on globalization on middle-income economies (MIEs). According to Garret, growth rates of MIEs have been stagnating since 1980 because of their inability to compete with high-income economies (HIEs) and low-income economies (LIEs), thus risk falling into a middle-income trap. He reasoned that people and countries must be competitive in either the knowledge economy, which rewards skills and institutions that promote cutting edge technological innovation, or the low-wage economy, which uses widely available technology to do low-skilled tasks at the lowest possible cost (Kanapathy. V, Herizal. H, Pasuk. P, and Pornthep. B, 2013).

However, the term was subsequently popularized by Gill and Kharas (2007); Commission on Growth and Development (2008), where are defined in accordance with the World Bank's classifications by income group ${ }^{1}$.(Agénor, Canuto, Jelenic, 2012).

According to Kenichi Ohno (2009), he characterizes the middle-income trap as the glass ceiling between the second and third stages of the four stages of catching-up industrialization that he maps out.

After that, both the World Bank classifications indicators (2010, 2013) and J. Felipe, A. Abdon, and U. Kumar (2012) distinguish the lower and upper middle-income groups. Their classification methods are similar but their data are drawn from different sources. Further then, Woo (2012), P. Robertson and Y. Lonfeng (2013) compared the fourth world economies relative to the US income level; and their studies are also based on different databases. Although, Yanrui, $\mathrm{Wu}$ (2013) make a comparison beyond those classification methods of middle-income countries. After that, his study devoted to an extension in the literature by linking the middle-income trap concept with the role of productivity in economic growth among various groups of countries.

In addition, Tran, V. T (2013) has drawn an analytical framework that stand basically on three economic development stages categorized in four (04) main groups of

\footnotetext{
1. "Middle-income economies", given by http://data.worldbank.org/about/countryclassifications
}

countries. Then, he tried to explain and localize the middle income trap phenomenon through the Association of South East Asian Nations (ASEAN) experiences to achieve the high income level (see also: Aaron. F, Ejaz. G, Saurabh. M, 2013, on the Malaysian case). While, Eichengreen Barry, Donghyun Park and Kwanho Shin $(2012,2013)$ presented an alternative perspective using the Penn World Tables (PWT) data to occur the slowdown growth issue on group of countries.

Whereas, Anna. J, Arne. N, and José. R. P (2012) have built a comparative analysis between the Asian and Latin America countries, based on two main points. The first one concerns an illustration of differences in the process of structural transformation, both with regard to sector productivity and employment absorption. Where in second point, they adopt the Product Space methodology to compare the structural transformation that took place in both regions.

Otherwise, (Agénor and Canuto 2012, 2015) have recently developed an alternative characterization of a middle-income trap; where they assumed that the productivity slowdowns are a major cause of middle-income traps.

Depending to all the cases of countries studied above. We resume that all those literatures are focuses basically on slowdown growth (stagnation) development issues, even the main solutions and practices proposed to avoid the middle-income trap. Whether this researches essays to concentrate specially on evidences and experiments of South East Asian countries (Malaysia, Thailand, Indonesia, Philippines), China, and Latin Americas countries (Brazil, Argentina, Peru, ....etc.).

\subsubsection{Our Contribution to the Literature}

Our contribution to the literature structured in two main axes. First, we tried to conduct a comparative analysis between Algeria and other group of MENA countries, that they share the most similar characteristics.

Second, our paper try essentially to diagnosis and treat the main reasons and policies that fall the Algerian economy in middle income trap among a selected MENA countries. Moreover, we suggests as policy implications, the key strategies and serious solutions for the Algerian economy in order to avoid falling in that trap. As result - depending to the previous research - our work appears as the first study interested and related in particular to the Algerian case among the African and Middle East countries.

\subsection{Concept Background of the Middle-Income Trap}

The "middle-income country trap" is a development stage that characterizes countries that are squeezed between being low-wage producers and highly-skilled, fast-moving innovators. Countries caught in this trap tend to grow slower and often fall behind. Cost advantages in labor-intensive sectors, such as the manufactured exports, which once drove growth, start to decline in comparison with lower-wage poor country producers (Gill and Kharas, 2007).

The concept of the middle-income trap has emerged only recently in the discussions on economic development. Scholars agree that the lack of upgrading towards more 
knowledge-intensive production is at the core of the middle-income trap. Nevertheless, they differ in how they contextualize the issue. Some see it as a typical problem for middle-income countries in the process of accumulating technological capabilities. Others, stress that the current globalization process - especially the rise of China-is turning a middle-income dilemma into a possible middle-income trap (Eva paus, 2012).

Whereas, Jesus Felipe, Arnelyn Abdon, and Utsav Kumar (2012); tries to provide a working definition to the "middle-income trap" in two parts; where the first one is to categorize the economies of 124 countries in four basic groups (with GDP per capita in 1990 PPP). While the second one, based on calculations and analysis for the historical income transitions.

Therefore, Fang Cai (2012), as discussed in his paper, state that the concept of middle-income trap is in line with the framework of the mainstream economic growth theories.

While, a statistical definition of a middle-income trap was been proposed by P. Robertson \& Y. Longfeng (2013); in which they have derived a simple time-series test to a sample of middle-income trap countries. Finally found that the concept survives a rigorous scrutiny of the data, even the half of the sample satisfy their definition, including two former East Asian miracle economies.

Through the most definitions cited above, Yanrui Wu (2013) tries to enclose all those in his contribution research and make a comparison against their classification methods of middle-income countries. After that, his study devoted to relate the middle-income trap concept with the role of productivity in economic growth for various groups of countries.

Further then, and basing on World Bank classification indicators (2012), the world economy today is categorized into four groups: low-income countries with per capita GNI of US\$975 are categorized under group 1. The countries in this group are still fighting against extreme poverty and basic living standards conditions. Group 2 is composed of middle-income countries that achieve higher GNI per capita, but yet, failed to become a fully developed countries. Countries of group 2 have reached middle-income level many years ago, but have experienced low or no growth since then. Many Latin American countries belong to this group. Income per capita GNI in this group varies between US\$976 to US\$11,906. Group 3 contains countries that have recently attained or are approaching the middle-income level. Group 4 is composed of high-income countries such as members of the Organization for Economic Co-operation and Development (OECD) and several others. Countries that fall in group 4 experience a per capita GNI higher than US\$11,806 and high living standards. The countries in group 2 can be referred as old middle-income countries; those in group 3 can be called new middle-income countries (Tran, 2013).

Middle income countries after a successful transition from low to middle-income level, tend to move forward and achieve high level of income; nevertheless, failing to do so drives them to remain below high-income level due to several reasons. A hard challenge of many developing countries is to avoid middle-income trap.

Basically, middle income level, according to 2012 GNI per capita, calculated using the World Bank Atlas method, as we can distinguish between: lower middle income (from 1,036 $\$$ to $4,085 \$$ ), and upper middle income (from $4,086 \$$ to 12,615 \$) (World bank data, 2013).

According to Kharas and Kohli (2011), most countries fall into the middle-income trap as a result of failure to adopt new technologies once they reach the middle-income status. They argued that there is a dire need for middle-income countries to put more emphasis on demand-side strategies rather than on supply-side policies. Initial arrangements allow for successful transition from low to middle-income, but not from middle to high-income. With escalating wages, middle-income economies lose their cost competitiveness in exports. New policies are, consequently, needed to develop new products, processes, and markets.

The basic framework analysis commences by looking at different stages that countries cross to become fully developed with high level of income. Figure 1 illustrates the various scenarios that a country may face. The path from B to C is a long process that transforms the country from an agricultural to an industrial economy; in this path, the economy experiences increasing shares of the various manufactures and services companies in total output and employment. In this stage, the economy experiences many aspects of structural change, including factor markets, technological levels, and comparative advantage (Tran, 2013). When the economy reaches point $\mathrm{C}$ - the middle-income stage-, those changes become major challenges which the country must overcome for successful transition to the high-income level.

Point from $\mathrm{B}$ to $\mathrm{C}$ is considered as an early stage of economic development. The key drive of the economy is labor and capital, where it is known by input driven economy. In this stage, such a growth pattern can be justified since labor is abundant. Capital is comparatively scarce but the need for it in initial investment in infrastructure and in industrial production has increasingly expanded, while technology remains underdeveloped. However, in order to achieve high-income level where growth is sustained, the country must be increasingly endowed with highly technological and managerial resources, and capital must be efficiently utilized. In other words, the growth of the economy should be Total Factor Productivity (TFP) intensive rather than capital and labor driven. Thus, the turning point between input-driven growth and TFP-based growth may approximately coincide with C (Alwyn, 1995).

Once the economy catches up with middle-income level (point C) by industrialization, and as wages rise, middle-income countries are increasingly losing their comparative advantage in labor-intensive industries. Eventually, these industries will fade away. In other words, middle-income countries become less competitive with less developed economies because of the increasing wage, and hard to compete with developed countries because of relatively weaknesses in technology and human capital. By 
then, further growth of middle-income countries must therefore increasingly rely on high skill-intensive industries and a deeper stock of physical and human capital. Middle-income countries are squeezed between low-wage -low-income competitor countries that dominate labor-intensive mature industries and the high-income country innovators that dominate industries experiencing rapid technological change. In brief, middle-income countries must successfully climb the development ladder and catch up with advanced countries in the transition to the high-income level.

What are the conditions for successful transformation of comparative advantage to avoid middle-income trap? Two conditions seem important (Tran, 2013). One is the timely shift of focus of policy and public sector investment in infrastructure and human capital so as to develop new technology and knowledge intensive industries. The second condition is high-quality institutions that generate and maintain a dynamic private sector which is innovative and sensitive to changes in international markets. Let us elaborate on these two areas.

On the shift of policy, promotion of higher education, applied research, and development of high quality infrastructure should be emphasized to move the economy toward the high-income level, which is characterized by high skill and knowledge intensity. One example of high quality infrastructure is telecommunications, which is particularly important for a knowledge economy (Alwyn, 1995).

The second condition for successful transformation of comparative advantage is the establishing of efficient institutions. In prior stages of development, sophisticated institutions are not necessary and the capacity for establishing such institutions is also not available. Given the factor endowment (agricultural resources, labor abundance), the direction of development has been quite clear so that policy formation has been simple. Government intervention, including establishment of state-owned enterprises, has been necessary and justifiable. Such "crude" institutions are not inappropriate at the input-driven growth stage.

To achieve a sustained growth, sophisticated institutions with high quality of technology are required. High institutions quality refers to high governance quality and wide stakeholder's participation in policy decisions process, effective cooperation among academics, policy makers and investors, and increasing investment in research and development (Rodrik, 2007).

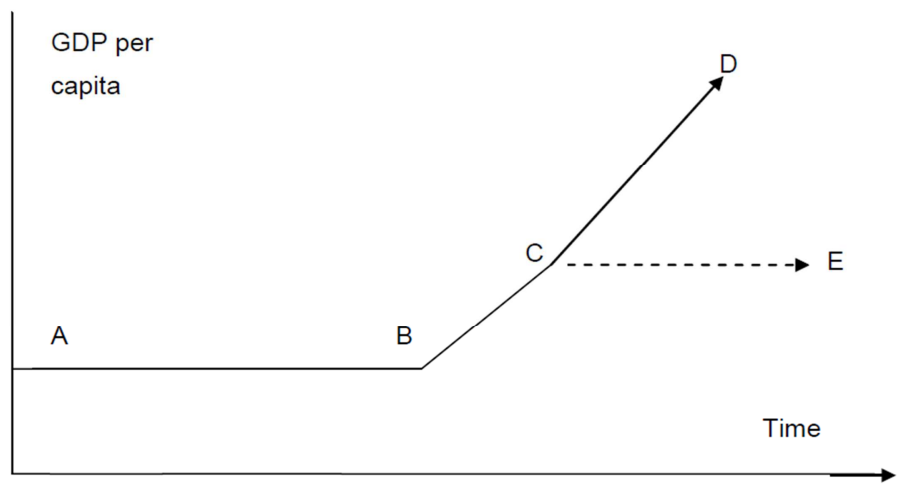

Source: Tran, 2013

Figure 1. Development stages of an economy.

\section{Methodology Analysis}

To achieve our goals, this study based on two methods analysis. First, we use the descriptive and historical method; to reveal and explain the main reasons that may affects the economic situation of Algeria. Second, we tried to give a comparative analysis method, in which to compare and analyse the main policies and economic facts that differs toward the world classification between Algeria and the other selected MENA countries.

\section{The Case of the Algerian Economy among other MENA Countries; Position \& Comparison}

Based on our objectives of this study, we focus fundamentally on analyzing the position of the Algerian economy, which is considered as one of the strategic members of MENA countries, and which its economic situation ranked as a "long middle-income trap" during the last 50 years from the independence (from 1963 to 2013) comparing with the other countries. The main reasons, factors; that effect the Algerian economy, will be discussed in our analysis.

\subsection{Algerian Economy Position}

Our analysis is based on World Bank data of GNI per capita (1963-2013). First of all, we will describe and explain across the following table \& graph, the Algerian GNI/per capita development graph only during the stated period. Second, across the same data, we will try to give a comparison between Algeria and the MENA countries in order to better clarify the consequences that may cause variances, which affects the Algerian situation.

Looking to the graph below, firstly, we have to indicate for missing observations (values) on the last four years 
(2010-2013); as we cannot show the fluctuations or any explanations in that period. However, with the available data set we are able to give a critical description of the figure 2 . Then, we can state generally that the graph tendency was in ascendant, beginning from 1547 \$ in 1963 to 2736 \$ in 1985 ; while it continued with some (troubles) volatility, particularly in 1966 (with 1475 \$). Moreover, in 1971 (with 1657 \$), it goes to decline from 1986 with 2686 \$ until 1994 with 2193 \$.

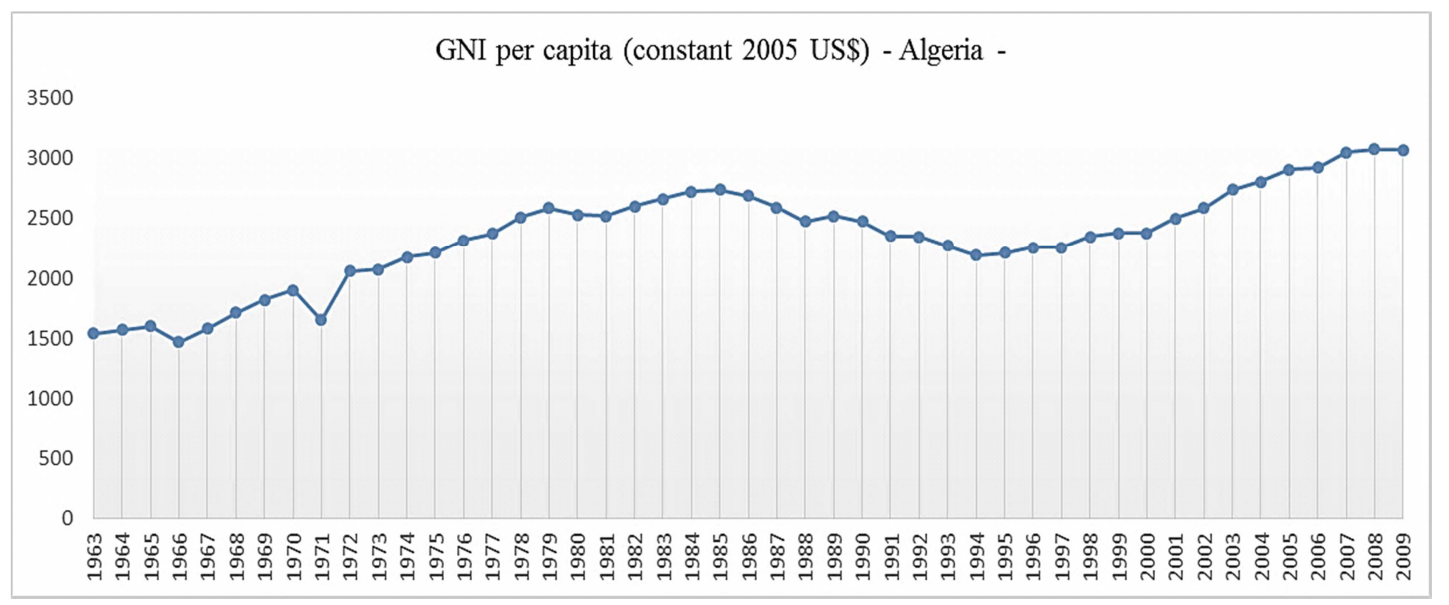

Source: By authors basing on World Bank Data (DWI 2014)

Figure 2. GNI per capita (constant 2005 US \$).

Finally, the growth tendency rises again slowly from 1995 with 2213 \$ to attain $3066 \$$ in 2009.

In general, the situation and GNI per capita varies frequently. These changes occur due to several factors and reasons which influences the economic situation in different stages during the studied period.

According to the first section - in theoretical part - and depending on our graph data on figure 1 , we can say that the Algerian economy belongs the group 2, which contains countries that have reached middle-income level for more than forty years, So their GNI per capita varies between ( $976 \$$ to $11.906 \$$ ) as cited above.

In other word; we may put the Algerian case in the middle stage (from B to C point) based on (Tran, 2013) graph analysis. That means, the Algerian economy is considered as in initial development stage, escape from poverty trap, also it was initial development of markets.

Up to this stage, and when we observe that the Algerian economy growth indicator attained 3,3\% (GDP growth in 2012), with an upper middle-income classification (WBI, 2014), so called in a development stage (point C), but !!, which growth strategies and policies have taken against this situation?! How could we state \& describe that the Algerian economy had fallen in a trap?

To answer these questions, we will show a brief historical passage about different strategies \& policies that were taken, and their effects on growth evolution during the last fifteen years from 1963.

The following table will give a resume of different growth strategies, policies, and programs that were applied by the Algerian government (from 1963- 2013).

Table 1. Growth strategies \& policies.

\begin{tabular}{|c|c|c|}
\hline Period & Growth Strategies \& policies & (Reasons-effects) on growth evolution \\
\hline $1962-1965$ & $\begin{array}{l}\text { * Agrarian Reform: The first economic policy is developed, adopted a policy } \\
\text { of self-management system, and the first form of governance known to the } \\
\text { Algerian economic system[1]. }\end{array}$ & $\begin{array}{l}\text { Centenarians migration from farms and industrial units and } \\
\text { technicians migration; created a very difficult and complex } \\
\text { situation. This situation may have influenced the decision } \\
\text { making for the first time after the independence. }\end{array}$ \\
\hline $1966-1979$ & $\begin{array}{l}\text { * The socialist approach: Algeria was one of the first allied with USSR, and } \\
\text { the second African country that assisted directly Moscow. } \\
\text { * Planning and Industrialization: transition from agriculture reform to the } \\
\text { exploitation of natural resources (Hydrocarbons)[2]. } \\
\text { During the 1960s and 1970s oil revenues began to rise dramatically and thus } \\
\text { the government shifted its economic sights to the oil industry. Extensive } \\
\text { industrialization took place and the economy flourished. Unfortunately, oil } \\
\text { prices dropped in the 1980s, negatively affecting the Algerian economy } \\
\text { which had become almost completely dependent on oil [3]. }\end{array}$ & $\begin{array}{l}\text { The choice of socialism came in many of the basic texts } \\
\text { starting from } 1956 \text { "Alsomam conference", which gave the } \\
\text { signal to self-management institutions, and ensured the } \\
\text { trend towards socialism after "Al-somam Conference" in } \\
\text { all national conventions. }\end{array}$ \\
\hline
\end{tabular}

[1] Parti Communiste International, «Algérie, hier et aujourd'hui », http://www.international-communist party.org/Francais/Relation/Algerie/Algerie5.htm

[2] Ibidem.

[3] Oil, Industry and Agriculture Driving Algeria's Economy, http://www.algeria.com/economy/ 


\begin{tabular}{|c|c|c|}
\hline Period & Growth Strategies \& policies & (Reasons-effects) on growth evolution \\
\hline & $\begin{array}{l}\text { *Economic Development Policy (1967-1977): } \\
\text { Algeria has known during this period three development schemes; a trio } \\
\text { planned, first planned quartet, and second planned quartet, in addition to the } \\
\text { complementary phase 1978- } 1979 \text { (Derouassi Messaoud, 2006). }\end{array}$ & $\begin{array}{l}\text { Algeria adopted the planning system as a means of } \\
\text { achieving development, where it was not able to be applied } \\
\text { before because of the newness of independence; and, on } \\
\text { the one hand, the lack of objective conditions that gave the } \\
\text { state control of national economic power capacity. }\end{array}$ \\
\hline $1980-1989$ & $\begin{array}{l}\text { *Decentralized development stage (1980-1989):Algeria has known during } \\
\text { this period two development schemes; the first planned Quintet (1980-1984), } \\
\text { and the second planned Quintet (1985-1989) (Derouassi Messaoud, 2006). }\end{array}$ & $\begin{array}{l}\text { The main reason is to get out of the difficult situation } \\
\text { defined by the national economy as well as to adapt to the } \\
\text { new international situation. }\end{array}$ \\
\hline $1990-1992$ & $\begin{array}{l}\text { *Economic reforms: Algeria in early eighties took several economic reforms } \\
\text { at the heart of its economy and its development, it emerged to go about } \\
\text { improving the functioning of the productive apparatus and the introduction } \\
\text { of factors, effectiveness and cost-effectiveness, and the selection of } \\
\text { decentralized decision-making. These concerns are embodied in a set of } \\
\text { regulatory procedures which are known economic reforms, represented the } \\
\text { economic reforms. Algeria carried out during the eighties in decimal } \\
\text { economic reform reform framing tools, restructuring of public institutions } \\
\text { followed by the independence of institutions (Derouassi Messaoud, 2006). }\end{array}$ & $\begin{array}{l}\text { Give a new role to public economic institutions, and find } \\
\text { new mechanisms to protect them from collapse. }\end{array}$ \\
\hline $1994-2000$ & $\begin{array}{l}\text { *Economic Development Policy under the new international circumstances: } \\
\text { this period contains different policies and practices in order to get more } \\
\text { dynamic and adaptability to the new economic situation, noting: } \\
\text { Privatization Policy, Foreign partnership (European Union), Foreign } \\
\text { investment, Accession to the World Trade Organization (Derouassi } \\
\text { Messaoud, 2006). } \\
\text { In the emergency context that prevailed in 2001, social and political } \\
\text { pressures have led to the establishment of the first public investment program } \\
\text { (Achour Tani. Y, 2014). }\end{array}$ & $\begin{array}{l}\text { Economic stability has been slow, at great cost, and was } \\
\text { accompanied by a high social cost. Growth remained weak } \\
\text { and unemployment has increased. }\end{array}$ \\
\hline $2001-2009$ & $\begin{array}{l}\text { Following the increase in oil prices, the government launched in } 2001 \text { an } \\
\text { economic recovery program followed in } 2004 \text {, by a stronger growth program } \\
\text { through which the growth rate was further adjusted (Achour Tani. Y, 2014). }\end{array}$ & \\
\hline
\end{tabular}

Source: Authors conception

\subsection{Comparison with MENA Countries}

As discussed previously, we shall make, as second objective of this study, a comparison of the Algerian case against the selected MENA countries, in order to reveal the main characters that effect the economic level on most of these countries, beside to the different aspects and levels of their economies. As result, we arrive to stand on the Algerian economy position between those countries.

In order to make this comparison illustrative and evident, we are going to select a determinant countries, where each one represents a group (number) of countries that have the most similar characters (business environment, investment policies, geographic location, ...etc.) between them, as listed in figure 3 as the following :

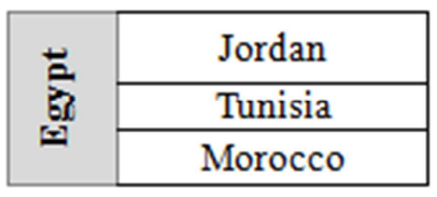

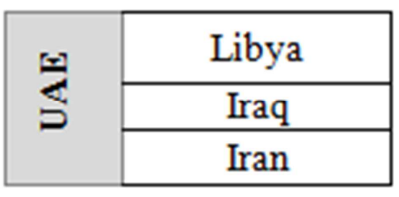

Source: Authors conception

Figure 3. Countries groups that have the similar characters.

The following graph (figure 4) will show a comparison between Algeria and the other selected MENA countries, in reference to their GNI per capita during the same studied period (1936-2013).

Observing figure 4, we should mention that there were many missing values concerning the GNI per capita of UAE, and YEMEN; so we may be unable to give the comparative analysis in that missing period. Whatever, back to our objective concerning the comparison between Algeria, and those selected countries, we can state that, there is a clear distinction between those countries depending to Algeria. First, we found that Yemen classified in low-income level from 1990 with 662 \$, to 853 \$ in 2010 . Then, we notice the Egyptian case too, in which it was been classified in low-income level since 1965 with 402 \$, to 1995 with 959 \$, after that, it reached the middle-income stage from 1996 (with 996 \$). Besides that, we observe, given the last compared countries that the UAE has fully classified in high-income 
level (even we have missed values until 2001), like OECD members, USA, Europe, and other Asian countries.

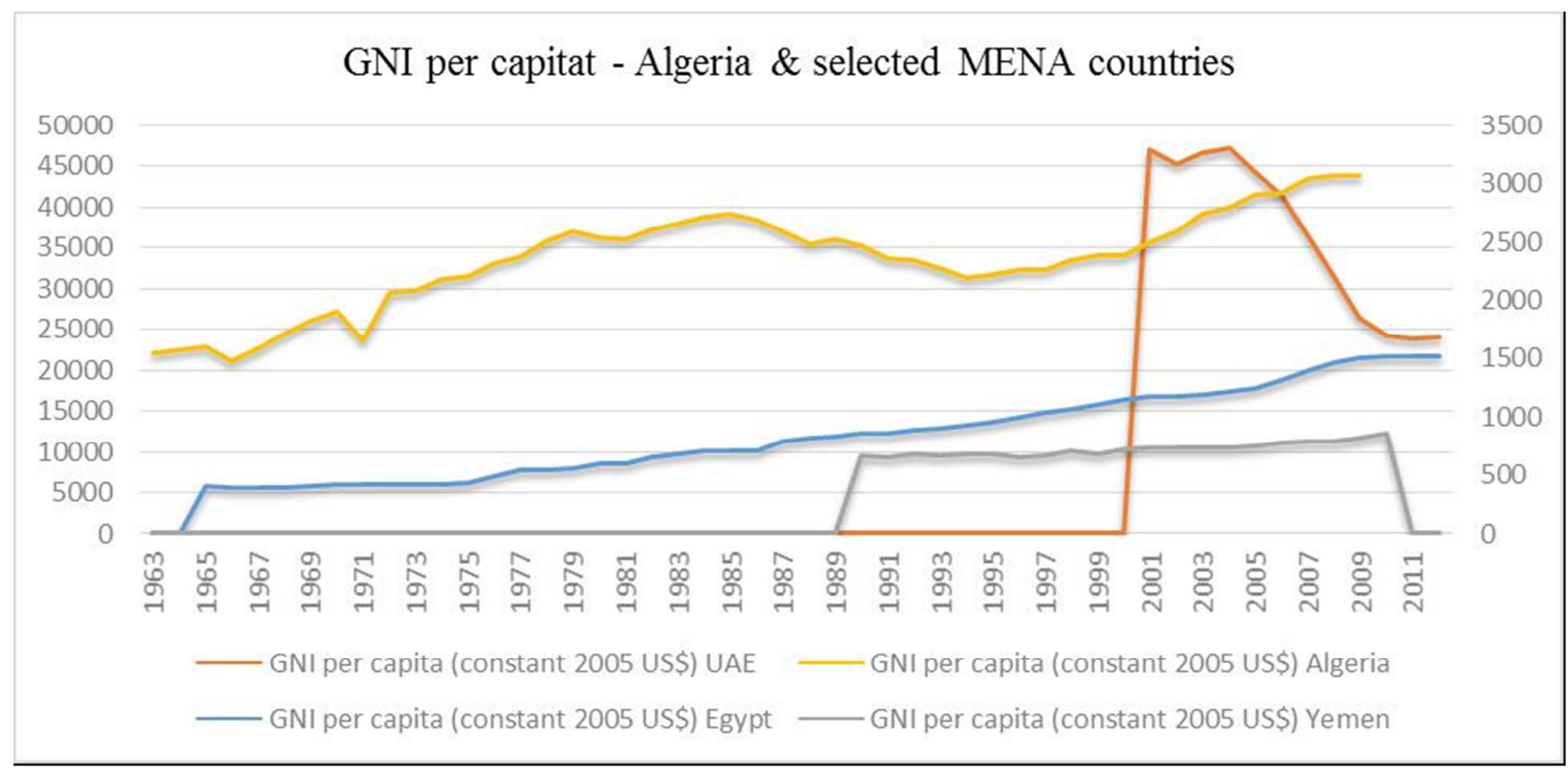

Source: By authors basing on WDI (2014)

Figure 4. Economic level classification -Algeria and selected MENA countries- (GNI per capita constant 2005\$).

We resume our comments and analysis expressed above, in the following table:

Table 2. Resume comparison between Algeria and selected countries.

\begin{tabular}{ll}
\hline Compared Countries (selected) & Algeria (middle-income) \\
\hline Egypt(from low to middle-income) & Algeria has a better position than Egypt; nevertheless, Algeria has experienced a long middle-income position. \\
Yemen(low-income) & Yemen is too far even from reaching the middle-income stage yet, seeing the Algerian case. \\
UAE(High-income) & Both of them are oil countries, however, UAE has attained a high-income class, even if, its GNI drop down from \\
\hline
\end{tabular}

Source: Authors conception based on figure 3 analysis

\section{Recommendation and Remedies Suggested as Way out from Middle-Income Trap}

Algeria has been in a state of - permanent instability - since 1965. The state as we know it today had faced the most destabilising domestic challenges:

\subsection{The Failed Economic Transition}

\subsubsection{An Economy Dependent with Hydrocarbons}

Algeria's economy is still heavily dependent on oil revenues. The oil and gas sector continues to generate about $97 \%$ of overall export resources, $70 \%$ of budget receipts and on average $37 \%$ of GDP. The sector is however looking at a downward trend in its production volume (205.82 million tons of oil equivalent in 2011, down from 233.30 million tons in 2007). This last has already resulted in a lesser contribution of the oil sector to GDP, from $43.7 \%$ in 2007 to $36.7 \%$ in 2011 and in a nearly $3.3 \%$ fall in the volume of hydrocarbon exports, from 133.15 million tons in 2007 to 110.81 million tons in 2011. The strategy to diversify revenue sources in Algeria includes a significant component of value creation in the hydrocarbons production chain. A major investment program is underway to strengthen national refining capacities and to develop the subcontracting industry, particularly in the field of petrochemicals.

\subsubsection{Less Participation of Agriculture and Industry}

The growth sector; the agricultural sector has been estimated at $13.7 \%$ in 2012 ; (compared to $10.5 \%$ in 2011 ) by virtue of the dynamics of the cereals, milk, meat and potatoes sectors. Its increase can also be attributed to the extension of the irrigated area, which has reached about one million hectares. The agricultural sector is estimated to have contributed to $10 \%$ of GDP in 2012 .

The contribution of the industrial sector to GDP stands at $4.2 \%$ of GDP in 2012 (just down from $4.3 \%$ in 2011) and has therefore not recovered its buoyancy of the 1990s (about $10 \%$ of GDP). Recovery in industry seems however to be starting up, as reflected by growth of the general industrial production index, which was $1.2 \%$ in 2012 (compared to $0.4 \%$ in 2011). This dynamic is due to the leather and footwear $(+15 \%)$ and the energy $(+11.4 \%)$ industries. The steel, metal, mechanical, electronic and electrical industries, as well as construction 
materials, showed performance well into 2012 .

\subsubsection{Non-efficiency in Macroeconomic Policies}

Fiscal policy remained expansionary so that public investments could be continued at the same pace and contains the strong social demand. The government's continued implementation of the public-investment program in connection with the (2010-2014) five-year plan (amounting to USD 286 billion) and its response to strong social demands for more purchasing power, jobs and housing had repercussions on public expenditure, which represented about $43.2 \%$ of GDP in 2012. The 2012 rise in expenditure is the result of wage increase granted in 2011, subsidies consumption prices and social transfers.

In 2012, the Bank of Algeria continued to focus on its monetary policy on controlling the money supply and the exchange rate, and monitoring inflation. Nonetheless, inflation rose sharply in 2012 to $8.9 \%$ (versus $4.5 \%$ in 2011 ). The current exchange-rate regime is characterised by a managed float of the value of the Algerian dinar. In 2012, the average exchange rate of the Algerian dinar appreciated against the euro by $0.05 \%$ and depreciated by $6.45 \%$ against the dollar, reflecting an alignment of the nominal rate of the dinar on its real market rate. The annual average exchange rate turned at EUR 102.10 and USD 77.50 per one dinar.

The country has in recent years undertaken the implementation of a program to modernise its banking and financial sector. On February 20, 2012, the Bank of Algeria issued a new regulation (No. 12-01) laying down the organization and operations principles of its risk-centralization division for enterprises and households, who are in charge of collecting, processing and saving data on credits that are granted by banks to their customers, and reporting it back to the banking network. In the same direction, the conditions for households to open a bank account have been eased, which should allow households greater access to ranking and financial services.

\subsubsection{Miss-Management of Public Sector}

As for transparency and governance, Transparency International ranked Algeria 10th out of 176 countries in 2012

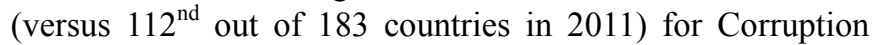
Perceptions Index, at $34^{\text {th }}$ out of 100 , a high score according to Transparency International. To improve indicators for Algeria, in 2012 the government continued to implement its action plan to fight against corruption. Actions to improve governance have included the elected bodies adoption of the law on budget regulations for 2010. The country has also stayed the course in publishing reports on the observance of the transparency standards and codes in monetary, financial and fiscal policy, and in banking supervision, prepared under partnership with the IMF (Article IV).

\subsubsection{The Absence of Private Sector}

Algeria's business climate is still facing a number of constraints, including administrative sluggishness in various areas such as starting a business, customs clearance and registering commercial activities, engendering delays in operations and significant transaction costs. The World Bank report doing Business 2013 ranks Algeria $152^{\text {nd }}$ out of 185 countries, down from $150^{\text {th }}$ out of 183 countries in the 2012 report. The private sector comprises 920307 enterprises, or about $98 \%$ of all production units and $52 \%$ of the total added value, but it mostly consists of small and very small enterprises (VSEs), accounting for about $90 \%$ of the sector. Most VSEs are small family businesses. In their search for new markets, domestic producers are facing strong competition from imported products and goods, some of which are sold at relatively very low prices. The resulting decline in the use of national capacities thus discourages investment and contributes to reducing long-term competitiveness.

\subsection{The Failed Social Development Program}

\subsubsection{Poverty Reduction}

Algeria has made serious progress in reaching the Millennium Development Goals (MDGs). It was 93rd out of 186 countries in the United Nations Development Program of Human Development Index (HDI) 2011 rankings and ranked among countries with medium human development with a 0.713 HDI. The country's per capita GDP was estimated at more than 4500 USD in 2011 (against USD 1610 in 2000). Absolute poverty has declined from $1.7 \%$ of the population in 1990 to $0.5 \%$ in 2011 . The share of the population with access to drinking water is $83 \%$, and that with access to improved sanitation facilities is $95 \%$. Despite this progress, Algeria is still facing major social challenges, mainly in unemployment, particularly among young people, in shortage of housing and in the quality of health care. According to 2011 survey of the national statistics bureau, the ONS (Office national des statistiques), unemployment affects about $10 \%$ of the Algerian working population and $22.4 \%$ of 15 to 24 year-old, with high disparities between men (19\%) and women (38.1\%).

\subsubsection{Social Protection}

The government allocates significant resources to social protection every year, and social-safety nets were reinforced in 2012 with integration into the 2012 finance law of the new arrangements approved in February 2011 to support consumer prices of cereals, sugar, cooking oil and milk. Also in line with the protection and preservation of purchasing power, the public authorities have ruled out any increase in the prices of electricity, water and petrol. In addition, the country-removed customs duties, value added tax (VAT) and company taxes on brown sugar and cooking oil, taking $41 \%$ off of the cost prices for these products. In exchange for these measures, decree No. 11-08 of 6 March 2011 capped consumer prices for regular refined cooking oil and white sugar, as well as their related production, import and distribution margins at both wholesale and retail stages. The government also decided to exempt the poultry industry from customs duties and VAT on inputs and finished products (maize, soybeans, other animal feed, etc.) from September $1^{\text {st }} 2012$ to August $31^{\text {st }} 2013$ in order to uphold the sector and allow accessibility to its products (consumption eggs and white meat). 


\section{Conclusions}

Our paper tried to give a comparative analysis overview about the middle income trap phenomenon, and focuses on the Algerian economy position among selected MENA countries. From this point, our results represents in the first side; a research contribution at least on some cases of MENA countries, and specially the Arab world, where many other previous researchs focuses only on the Asian and Latin Americas countries. Then, in the second side, our analysis results find that the Algerian economy have a better position than Egypt and Yemen, whether it suffered a serious slowdowns productivity levels and known a long growth stage rates during the studied period. However, Algeria is still behind UAE that classified in high-income level, where Algeria has known a slow growth rate during the last 50 years.

In other way, the Algerian economy situation let as summarize its development status in facts that the development strategy created unsustainable growth that collapsed with the reverse oil shock of 1986.

Delays in implementing economic reforms and political turmoil contributed to complicate the economic and social decline. By 1995 , poverty was again on the increase and reached almost $22 \%$. Income inequality in Algeria is not severe and the estimates give high growth elasticity. Rural poverty is almost double urban poverty. Given high urbanisation rate and high internal migration, population dynamics helps to moderately contain poverty.

Between 1995 and 1999, the real per capita expenditure stagnated despite a significant dis-inflation that resulted from the application of stringent demand management policies as part of adjustment programs. Successful stabilisation did not spur high growth.

As a consequence, poverty levels stagnated around its level in 1995. In fact, it would take almost nine years to bring poverty line to mean expenditure, assuming moderate growth. The significant improvement in the oil market outlook since the second half of 1999 helped to further improve the economic outlook of Algeria. If we simulate this optimist, medium term outlook and assuming that per capita real expenditure would grow by as much as real GDP per capita, poverty would decline rapidly to its 1995 level. Poverty is deeply rooted in Algeria since the days of colonialism. It is believed that before independence, between $65 \%$ and $25 \%$ of the Algerian population was living in destitute poverty. Post-independence development efforts helped reduce poverty levels rapidly. In 1966 , poverty level has reached $56 \%$ of the population, however, it was only $15 \%$ of Algiers city. This reflects the huge degree of regional disequilibrium.

The increase of oil prices and the substance of the development policy are the factors that make the fortune and misfortune of Algeria. Huge oil windfalls and central planning accelerated development noticeably and decreased poverty significantly. In 1980 , poverty head count reached $28.0 \%$. This trend continued and poverty reached $15 \%$ in 1988 .

According to these statistics and views, we resume finally that Algeria needs a real economic and social reform in order to success in the integration with global economic system.

\section{References}

[1] Achour Tani Yamna. (2014). The analysis of economic growth in Algeria. Doctoral thesis, University of Tlemcen, pp. 30 - 32.

[2] Agénor Pierre-Richard, and Otaviano Canuto. (2012). MiddleIncome Growth Traps. World Bank Policy Research Working Paper $\mathrm{N}^{\circ} 6210$.

[3] Agénor Pierre-Richard, and Otaviano Canuto. (2015). MiddleIncome Growth Traps. Research in Economics (Elsevier), http://dx.doi.org/10.1016/j.rie.2015.04.003.

[4] Agénor Pierre-Richard, Otaviano Canuto, and Michael Jelenic. (2012). Avoiding Middle-Income Growth Traps. World Bank Economic Premise (PREM Network), Nº8,.

[5] Anna Jankowska, Arne Nagengast and José Ramón Perea. (2012). The product space and the middle-income trap: comparing Asian and Latin American experiences. Working Paper No. 311. OECD DEVELOPMENT CENTRE.

[6] Aaron. F, Ejaz. G, Saurabh. M. (2013). How to Avoid Middle Income Traps? Evidence from Malaysia. Policy Research Working Paper $N^{\circ}$ 6427, World Bank.

[7] Cai, F. (2012). Is There a "Middle-income Trap"? Theories, Experiences and Relevance to China. China \& World Economy, 20: 49-61, doi: 10.1111/j.1749-124X.2012.01272.x

[8] Derouassi Messaoud. (2006), Fiscal policy and its role in achieving economic balance (the case of Algeria) 1990-2004. Doctoral thesis, University of Algeria, pp. 340-341.

[9] Eva Paus. (2012). Confronting the Middle Income Trap: Insights from Small Latecomers. St Comp Int Dev, Springer Science+Business Media, LLC .

[10] Eichengreen, Barry, Donghyun Park and Kwanho Shin (2012). When Fast Growing Economies Slow Down: International Evidence and Implications for China. Asian Economic Papers 11, pp.42-87.

[11] Eichengreen, Barry, Donghyun Park and Kwanho Shin (2013). Growth Slowdowns Redux: New Evidence on the Middle-Income Trap. Working Paper 18673, National Bureau of Economic Research.

[12] Gill, I, H Kharas with D Bhattasali et al. (2007), An East Asian Renaissance: Ideas for Economic Growth. Washington, DC, World Bank.

[13] Gianluca. G, Marco Vivarelli. (2010). Is inequality the price to pay for higher growth in middle-income countries? Revisiting the Kuznets hypothesis in the event of skill-biased technological change. J Evol Econ (2010) 20:265-306. Springer - Verlag.

[14] Hakim darbouche, (2011). Algeria's failed transition to a sustainable policy coming to yet another crossroads. MEDPR technical report $\mathrm{N}^{\circ} 8$.

[15] Jesus Felipe, Arnelyn Abdon, and Utsav Kumar .(2012). Tracking the Middle-income Trap: What Is It, Who Is in It, and Why?. Working Paper $N^{\circ} 715$, Levy Economics Institute of Bard College, NY, USA. 
[16] Kohli, H. A., \& Mukherjee, N. (2011), Potential Costs to Asia of the Middle-Income Trap. Global Journal of Emerging Market Economies, Vol. 3, Issue. 3: 291-311.

[17] Kharas, H., \& Kohli, H. (2011). What Is The Middle-Income Trap, Why Do Countries Fall into it, and How Can Be Avoided?, Journal of Emerging Market Economies, Vol. 3, Issue. 3: 281-289.

[18] Kanapathy. V, Herizal.h, Pasuk. P, and Pornthep. B. (2012). Middle-income trap: Economic myth, Political reality - Case studies from Malaysia and Thailand -. The Asia Foundation

[19] Ohno, K. (2009). Avoiding the middle-income trap. Renovating industrial policy formulation in Vietnam. ASEAN Economic Bulletin, Vol $26 \mathrm{~N}^{\circ} 1$, pp 25-43. Published by Institute of Southeast Asian Studies

[20] Peter E. Robertson, Longfeng Ye. (2013). On the Existence of a Middle Income Trap. Economics Discussion Paper 13.12, University of Western Australia, http://ssrn.com/abstract=2227776

[21] Rodrik, D. (2007). One Economics Many Recipes: Globalization, Institutions, and Economic Growth. Princeton, NJ: Princeton University Press.
[22] Seddiki Malika. (2013). Public Investment and Governance in Algeria: What Relationship? International conference, University of Setif 1, Algeria.

[23] Tran, V. T. (2013). The Middle-Income Trap: Issues for Members of the Association of Southeast Asian Nations. ADBI Working Paper $\mathrm{N}^{\circ}$. 421, Tokyo: Asian Development Bank Institute, May 2013.

[24] World Bank data. (2013). Country and lending groups, http://data.worldbank.org/about/country-classifications/countr $\mathrm{y}$-and-lending-groups\#Upper_middle_income, Accessed 29 Mars 2014.

[25] World Development Indicators (2014). http://databank.worldbank.org/data/views/variableselection/sel ectvariables.aspx? source=world-development-indicators\#s_g, Accessed 02nd April 2014.

[26] Young, Alwyn. (1995). The tyranny of numbers: confronting the statistical realities of the East Asian growth experience, The Quarterly Journal of Economics, 110, (3), Oxford University Press, pp. 641-680.

[27] Yanrui Wu. (2013). Productivity, Economic Growth and Middle Income Traps: Implications for China. Business School - University of Western Australia. 